\title{
RANCANG BANGUN MEDIA PEMBELAJARAN E-LEARNING DI SMA MUHAMMADIYAH 1 DENPASAR, BALI
}

\author{
Made Hanindia Prami Swari ${ }^{1)}$ Lintang Perdana Rochmat Sugiharto $^{2)}$ \\ Program Studi Teknik Informatika ${ }^{1)}$ \\ Fakultas Ilmu Komputer, Universitas Pembangunan Nasional "Veteran" Jawa Timur, Jawa Timur \\ Program Studi Teknik Informatika ${ }^{2)}$ \\ STMIK STIKOM Indonesia, Denpasar, Bali \\ hanindia.pramiswari@gmail.com ${ }^{1)}$ lintang2323@gmail.com ${ }^{2)}$
}

\begin{abstract}
New concepts and techniques in teaching have been developed to support conventional methods that rely solely on one-way teaching methods in the classroom. One of the teaching methods that are developing in the present is e-learning. E-learning can help teachers to distribute their teaching materials without having to be in the classroom by using the internet. This can be utilized when teachers are unable to attend class. So, that the distribution of materials, assignments or quizzes or even discussions between teachers and students can still take a place. Teaching and learning activities face-to-face in high school Muhammadiyah 1 Denpasar experienced have a obstacles, because teachers who have busy outside the school either in the organization or in the Muhammadiyah foundation. So, the teachers can not teach in the classroom. This research was conducted to build supporting learning media at SMA Muhammadiyah 1 Denpasar that can assist teachers in delivering all teaching materials online. So, that students can access teaching materials anywhere and can be used as an additional discussion media to discuss lesson material that has not been completed and can be useful as media in delivering and collecting assigned tasks
\end{abstract}

Keywords : E-learning, Internet, Online

\begin{abstract}
ABSTRAK
Berbagai konsep dan teknik baru dalam pengajaran telah banyak dikembangkan untuk mendukung metode konvensional yang hanya mengandalkan pada metode pengajaran satu arah di kelas. Salah satu metode pengajaran yang sedang berkembang di masa sekarang adalah e-learning. E-learning dapat membantu para pengajar dalam mendistribudikan bahan ajar mereka tanpa harus berada di kelas dengan menggunakan internet, hal ini dapat dimanfaatkan saat guru berhalangan hadir dikelas, sehingga pendistribusian materi, tugas atau quiz atau bahkan diskusi antara guru dan siswa tetap dapat berlangsung. Kegiatan belajar mengajar secara tatap muka di SMA Muhammadiyah 1 Denpasar mengalami kendala, karena guru yang memiliki kesibukan di luar sekolah baik di organisasi atau di yayasan Muhammadiyah sehingga guru tidak dapat mengajar di kelas. Penelitian ini dilakukan untuk membangun media pembelajaran pendukung pada SMA Muhammadiyah 1 Denpasar yang dapat membantu pengajar dalam menyampaikan semua bahan ajar secara online sehingga siswa dapat mengakses bahan ajar dimana saja dan dapat dijadikan media diskusi tambahan untuk membahas materi pelajaran yang belum tuntas serta dapat berguna sebagai media dalam menyampaikan dan mengumpulkan tugas-tugas yang di berikan.
\end{abstract}

Kata kunci : E-learning, Internet, Online

\section{PENDAHULUAN}

Pembangunan dunia pendidikan yang selalu mengalami perkembangan pesat seiring dengan laju perkembangan teknologi informasi yang sangat beraneka ragam. Diperlukan peningkatan mutu dan mekanisme pelayanan di bidang pendidikan agar lebih berdaya guna dan berhasil guna. Sehingga Sumber Daya Manusia (SDM) yang diciptakan dapat berpartisipasi dalam membangun dunia luar sesuai dengan kemampuannya.

Pembelajaran merupakan unsur yang sangat penting dalam pendidikan di Indonesia. Dalam pembelajaran terdapat berbagai macam strategi dan metode yang dapat digunakan sesuai dengan kondisi yang ada. Terlaksananya strategi pembelajaran yang meliputi pengajaran, diskusi, membaca, penugasan, presentasi dan evaluasi tergantung pada satu atau lebih tiga mode 
dasar komunikasi sebagai berikut (Boettcher, 1999): a.Dialog/komunikasi antara guru dengan siswa b. Dialog/komunikasi antara siswa dengan sumber belajar c. Dialog/komunikasi diantara siswa.

Dalam pendidikan di Indonesia, komunikasi antara guru dengan siswa mendapat porsi besar. Hal ini terbukti dengan adanya pembelajaran tatap muka di kelas yang sudah menjadi rumus umum dalam pendidikan. Keterlibatan langsung antara pendidik dengan peserta didik membuat hubungan emosi yang ada dalam pembelajaran yang bersifat tatap muka ini menjadi lebih intens.

Berdasarkan hasil wawancara yang dilakukan penulis terhadap kepala sekolah SMA Muhammadiyah 1 Denpasar Bapak Lahmuddin Cik Ujang, M.Pdi., komunikasi tersebut menjadi kendala karena guru yang memiliki kesibukan di luar sekolah baik di organisasi atau di yayasan Muhammadiyah sehingga guru tidak dapat mengajar di kelas. Menurut hasil dari pengamatan yang dilakukan oleh penulis berupa kuesioner, Hal tersebut beberapa kali dikeluhkan oleh siswa karena di satu kondisi mereka ketinggalan materi yang seharusnya disampaikan di pertemuan sebelumnya. Selain itu, guru juga mengalami kesulitan dalam mengelola tugas yang diberikan, seperti siapa saja yang sudah mengerjakan tugas dan memberikan nilai tugas secara langsung saat guru berhalangan hadir.

Untuk itu, dibutuhkan suatu media alternatif yang dapat menjadi sarana kegiatan belajar mengajar dan diskusi saat guru tidak dapat mengajar di kelas yaitu e-learning. $E$ learning adalah media yang memanfaatkan internet untuk mendistribusikan materi pembelajaran, sehingga siswa dapat mengakses darimana saja (Rosenberg, 2001). Di samping itu $e$-learning juga dapat menjadi sarana pendukung untuk mengelola dan memudahkan dalam penyebaran materi, artikel, makalah, video pembelajaran yang berkaitan dengan ilmu pengetahuan.

Dengan latar belakang masalah yang telah dikemukakan sebelumnya dan berdasarkan hasil kuesioner yang telah dilakukan, penulis memutuskan untuk membangun "Media Pembelajaran Online (e-learning) Pada SMA Muhammadiyah 1 Denpasar". Pada media ini guru dapat mengupload materi saat berhalangan hadir sehingga lebih praktis dalam penyebaran materi kepada siswa saat guru berhalangan hadir. Untuk pemahaman siswa terhadap materi, dapat dibantu dengan E-book yang nantinya akan diupload oleh guru. Siswa dapat mendownload dan membaca E-book sebagai referensi tambahan dalam belajar.

\section{TINJAUAN PUSTAKA}

Terdapat beberapa penelitian yang telah dilakukan oleh peneliti sebelumnya terkait pembuatan media pembelajaran e-learning. Penelitian yang dilakukan oleh Pratama (2016) yang berjudul "Rancang Bangun Eleraning untuk mata pelajaran akuntasi kelas 11 IPA dan IPS (Studi Kasus SMA Negeri 8 Denpasar)". Penelitian ini bertujuan untuk membuat e-learning untuk mata pelajaran akuntansi kelas 11 IPA dan IPS di SMA Negeri 8 Denpasar, untuk memberikan alternatif yaitu e-learning yang dapat diakses dimana saja dan kapan saja sehingga mendukung proses pendidikan di SMA Negeri 8 Denpasar. Penelitian terdahulu selanjutnya dilakukan oleh Sriwihajriyah (2012) dengan judul "Sistem Pembelajaran dengan Elearning untuk Persiapan Ujian Nasional Pada SMA Pusri Palembang". Penelitian ini bertujuan untuk membantu belajar para siswa SMA Pusri Palembang karena terdapat fungsi diantaranya download materi, mengerjakan latihan, ujian sehingga siswa tidak terpaku pada metode belajar konvensional. Perbedaan penelitian terdahulu dengan yang dilakukan sekarang adalah terdapat pada studi kasus dan fitur yang ditawarkan. Penelitian sekarang akan menambahkan fitur $e$-book dan forum diskusi yang dapat digunakan untuk berdiskusi oleh guru dan siswa. Adapun beberapa teori pendukung yang digunakan dalam penelitian ini diantaranya mengenai Sistem Informasi, Analisis Sistem, ELearning, Website, PHP, HTML, MySQL, XAMPP, PhpMyAdmin, Basis Data, UML, Use Case Diagram, Activity Diagram, Sequence Diagram, Class Diagram, Metode Slovin, dan Black Box Testing.

A. Sistem Informasi

Menurut Hutahaean $(2014,2)$, sistem adalah suatu jaringan kerja dari prosedur-prosedur yang saling berhubungan, berkumpul bersama-sama untuk melakukan kegiatan atau untuk melakukan sasaran yang tertentu. Pendekatan sistem yang merupakan jaringan kerja dari prosedur lebih menekankan urutanurutan operasi di dalam sistem. Sedangkan menurut Sutabri (2012, 6) Pada dasarnya sistem adalah sekelompok unsur yang erat hubungannya satu dengan yang lain, yang berfungsi bersama-sama untuk mencapai tujuan tertentu. 
Informasi adalah data yang diolah menjadi bentuk yang lebih berguna dan lebih berarti bagi yang menerimanya, sedangkan data merupakan sumber informasi yang menggambarkan suatu keadian yang nyata (Mulyanto, 2009, 12). Informasi merupakan data yang diolah menjadi bentuk yang lebih berguna dan lebih berarti bagi yang menerimanya (Jogiyanto, 2009, 8).

\section{B. Analisis Sistem}

Menurut Hanif (2007, 44), analisis sistem adalah teknik pemecahan masalah yang menguraikan bagian-bagian komponen dengan mempelajari seberapa bagus bagianbagian komponen tersebut bekerja dan berinteraksi untuk mencapai tujuan mereka. Menurut Hanif (2007, 45), tujuan utama dari analisis sistem adalah sebagai berikut:

1. Menentukan kelemahan dari proses-proses bisnis pada sistem lama untuk bisa menentukan kebutuhan dari sistem baru.

2. Menentukan tingkat kelayakan kebutuhan sistem baru tersebut di tinjau dari beberapa aspek, di antaranya ekonomi, teknik, operasional, dan hukum.

\section{E-learning}

Menurut C. Koran (2002), e-learning merupakan sembarang pengajaran dan pembelaran yang menggunakan rangakian elektronik (LAN, WAN, atau internet) untuk menyampaikan isi pembelajaran, interaksi, atau bimbingan. Ada pula yang menafsirkan $e$ learning sebagai bentuk pendidikan jarak jauh yang dilakukan melalui media internet. Sedangkan Dong (Yazdi, 2012), mendefinisikan e-learning sebagai kegiatan belajar asynchronous melalui perangkat elektronik komputer yang memperoleh bahan belajar yang sesuai dengan kebutuhannya.

\section{Web}

Menurut Pohan $(2014,1)$ World Wide Web atau WWW atau juga dikenal dengan web adalah salah satu layanan yang didapat oleh pemakai komputer yang terhubung ke internet dari sekedar informasi "sampah" atau informasi yang tidak berguna sama sekali sampai informasi yang serius dari informasi yang gratisan sampai informasi yang komersial. Website atau situs dapat diartikan sebagai kumpulan halaman-halaman yang digunakan untuk menampilkan informasi teks, gambar diam atau gerak, animasi, suara, dan atau gabungan dari semuanya itu baik yang bersifat statis maupun dinamis yang membentuk suatu rangkaian bangunan yang saling terkait dimana masing-masing dihubungkan dengan jaringan-jaringan halaman (hyperlink).

\section{E. $P H P$}

Menurut Hakim (2009, 11), PHP (Hyperlink Preprocessor) merupakan bahasa pemrograman yang digunakan secara luas untuk penanganan pembuatan dan pengembangan sebuah situs web dan bisa digunakan bersamaan dengan HTML. PHP diciptakan oleh Rasmus Lerdorf pertama kali pada tahun 1994. Pada awalnya PHP adalah singkatan dari Personal Home Page Tools. Selanjutnya diganti menjadi FI Forms Interpreter. Sejak versi 3.0, nama bahasa ini diubah menjadi PHP: "Hypertext Preprocessor" dengan singkatannya PHP.

\section{F. HTML}

Merupakan bahasa yang digunakan untuk menulis halaman web. Biasanya mempunyai ekstensi .htm, .html, atau .shtml.html tersusun atas tag-tag, digunakan untuk menentukan tampilan dari dokumen HTML yang diterjemahkan oleh browser. Tag HTML tidak case sensitive. Jadi bisa menggunakan $<$ HTML $>$ atau $<$ html $>$. Keduanya menghasilkan output yang sama. HTML berasal dari bahasa SGM (standart generalized markup language) yang penulisannya disederhanakan. HTML dapat dibaca oleh berbagai platform.

\section{G. $M y S Q L$}

Menurut Prasetyo (2004, 18), MYSQL merupakan salah satu database server yang berkembang di lingkungan open source dan didistribusikan secara free (gratis) dibawah lisensi GPL. MYSQL merupakan RDBMS yaitu program yang memungkinkan pengguna database untuk membuat, mengelola, dan menggunakan data pada suatu model relational. Dengan demikian, tabel-tabel yang ada pada database memiliki relasi antara satu tabel dengan tabel lainnya.

\section{H. $X A M P P$}

XAMPP adalah sebuah software yang berfungsi untuk menjalankan website berbasis PHP dan menggunakan pengolah data MySQL di komputer lokal. XAMPP berperan sebagai server web pada komputer anda. XAMPP juga dapat disebut sebuat Cpanel server virtual, yang dapat membantu melakukan preview sehingga dapat memodifikasi website tanpa harus online atau 
terakses dengan internet (Wicaksono, 2008, 7).

\section{PhpMyAdmin}

Menurut Firdaus (2007, 51), PhpMyAdmin adalah suatu program open source yang berbasis web yang dibuat menggunakan aplikasi PHP. Program ini mempermudah dan mempersingkat kerja penggunanya. Dengan kelebihannya, para pengguna awam tidak harus paham sintak-sintak SQL dalam pembuatan database dan tabel.

\section{J. Basis Data}

Menurut Rosa dan Shalahuddin (2013), sistem basis data (database) adalah sistem terkomputerisasi yang tujuan utamanya adalah memelihara data yang sudah diolah atau informasi dan membuat informasi tersedia saat dibutuhkan. Pada intinya basis data adalah media untuk menyimpan data agar data dapat diakses dengan mudah dan cepat.

\section{K. Unified Modelling Language}

Unified Modelling language (UML) adalah keluarga notasi grafis yang didukung oleh meta-model tunggal, yang membantu pendeskripsian dan system perangkat lunak, khususnya sistem yang berorientasi objek. Definisi ini merupakan definisi yang sederhana. Pada kenyataannya, pendapat orang-orang tentang UML berbeda satu sama lain. Hal ini dikarenakan oleh sejarahnya sendiri dan oleh perbedaan persepsi tentang apa yang membuat sebuah proses rancang bangun perangkat lunak efektif (Fowler, 2005, 1).

\section{Use Case Diagram}

Use case adalah teknik untuk merekam persyaratan fungsional sebuah sistem. Use case mendeskripsikan iteraksi tipikal antara para pengguna sistem dengan sistem itu sendiri, dengan memberi sebuah narasi tentang bagaimana sistem tersebut digunakan (Fowler, 2005, 141).

Berikut merupakan simbol-simbol yang digunakan dalam Use Case Diagram :

Tabel 1. Simbol Use Case DIagram

\begin{tabular}{l|l} 
Simbol & Deskripsi \\
\hline
\end{tabular}

\begin{tabular}{|c|c|}
\hline Use Case & $\begin{array}{l}\text { Fungsionalitas } \\
\text { yang } \\
\text { disediakan } \\
\text { sistem sebagai } \\
\text { unit-unit yang } \\
\text { saling bertukar } \\
\text { pesan antar } \\
\text { unit atau aktor, } \\
\text { biasanya } \\
\text { dinyatakan } \\
\text { dengan } \\
\text { menggunakan } \\
\text { kata kerja di } \\
\text { awal di awal } \\
\text { frase nama } \text { use } \\
\text { case }\end{array}$ \\
\hline Aktor/Actor & $\begin{array}{l}\text { Orang, proses } \\
\text { atau sistem } \\
\text { lain yang } \\
\text { berinteraksi } \\
\text { dengan sistem } \\
\text { informasi yang } \\
\text { akan dibuat di } \\
\text { luar sistem } \\
\text { informasi yang } \\
\text { akan dibuat itu } \\
\text { sendiri, jadi } \\
\text { walaupun } \\
\text { simbol dari } \\
\text { aktor adalah } \\
\text { gambar orang, } \\
\text { tapi aktor } \\
\text { belum tentu } \\
\text { merupakan } \\
\text { orang. }\end{array}$ \\
\hline Asosiasi/Association & $\begin{array}{l}\text { Komunikasi } \\
\text { antara aktor } \\
\text { dan use case } \\
\text { yang } \\
\text { berpartisipasi } \\
\text { pada use case } \\
\text { atau use case } \\
\text { memiliki } \\
\text { interaksi } \\
\text { dengan } \text { aktor }\end{array}$ \\
\hline $\begin{array}{r}\text { Ekstensi/Extend } \\
<<\text { extend }>>\end{array}$ & $\begin{array}{l}\text { Relasi use } \\
\text { case tambahan } \\
\text { ke sebuah use } \\
\text { case yang } \\
\text { ditambahkan } \\
\text { dapat berdiri } \\
\text { sendiri walau } \\
\text { tanpa use case } \\
\text { tambahan itu, } \\
\text { mirip dengan } \\
\text { prinsip } \\
\text { inheritance } \\
\text { pada }\end{array}$ \\
\hline
\end{tabular}




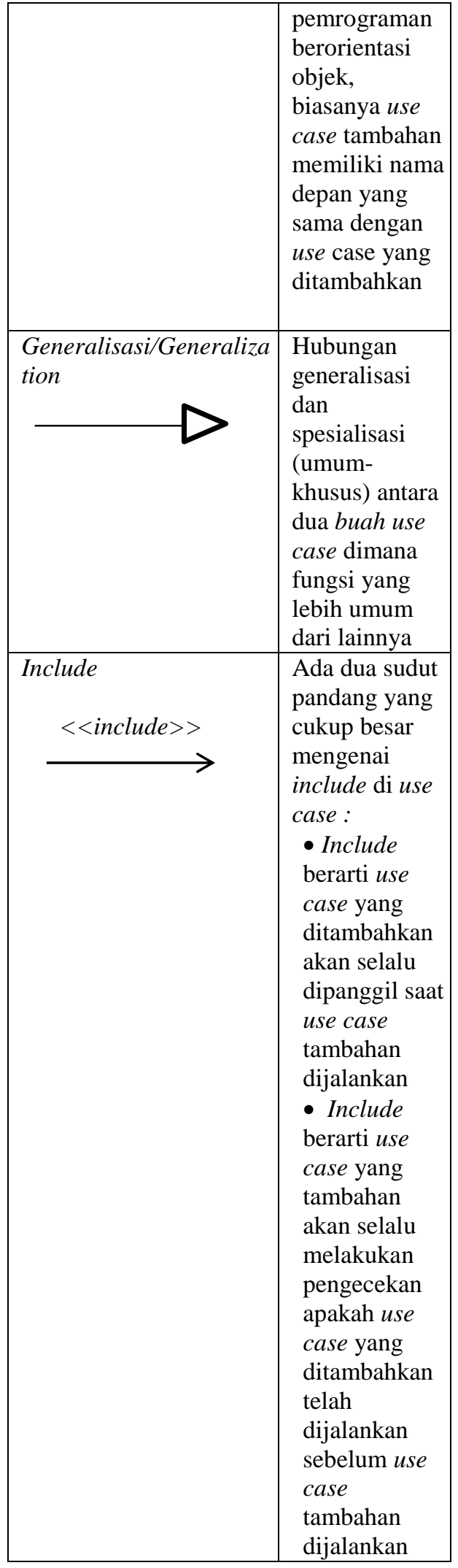

M. Activity Diagram

Activity diagram adalah teknik utnuk menggambarkan logika prosedural, proses bisnism dan jalur kerja. Dalam beberapa hal, diagram ini memainkan peran mirip sebuah diagram alir, tetapi perbedaan prinsip antara diagram ini dan notasi diagram alir adalah diagram ini mendukung behavior paralel (Fowler, 2005, 163).

Berikut merupakan simbol-simbol yang digunakan dalam Activity Diagram :

Tabel 2. Simbol Activity Diagran

\begin{tabular}{|c|c|}
\hline Simbol & Deskripsi \\
\hline Status Awal & $\begin{array}{l}\text { Status awal } \\
\text { aktivitas sistem, } \\
\text { sebuah diagram } \\
\text { aktivitas } \\
\text { memiliki } \\
\text { sebuah status } \\
\text { awal. }\end{array}$ \\
\hline Aktivitas & $\begin{array}{l}\text { Aktivitas yang } \\
\text { dilakukan } \\
\text { sistem, aktivitas } \\
\text { biasanya } \\
\text { diawali dengan } \\
\text { kata kerja }\end{array}$ \\
\hline Percabangan/decision & $\begin{array}{l}\text { Asosiasi } \\
\text { percabangan } \\
\text { dimana jika ada } \\
\text { pilihan aktivitas } \\
\text { lebih dari satu }\end{array}$ \\
\hline Status Akhir & $\begin{array}{l}\text { Status akhir } \\
\text { yang dilakukan } \\
\text { sistem, sebuah } \\
\text { diagram } \\
\text { aktivitas } \\
\text { memiliki } \\
\text { sebuah status } \\
\text { akhir }\end{array}$ \\
\hline Swimlane & $\begin{array}{l}\text { Memisahkan } \\
\text { organisasi } \\
\text { bisnis yang } \\
\text { bertanggung } \\
\text { jawab terhadap } \\
\text { aktivitas yang } \\
\text { terjadi }\end{array}$ \\
\hline
\end{tabular}

N. Sequence Diagram

Sebuah sequence diagram, secara khusus, menjabarkan behavior sebuah skenario tunggal. Diagram tersebut menunjukkan sejumlah objek contoh dan pesan-pesan yang 
melewati objek-objek ini didalam use case. Sequence diagram menunjukkan interaksi dengan menampilkan setiap partisipan dengan garis alir secara vertikal dari atas ke bawah (Fowler, 2005, 81).

Berikut merupakan simbol-simbol yang ada pada Sequence Diagram (Rosa dan Shalahuddin, 2015, 165-167) :

Tabel 3. Simbol Sequence Diagram

\begin{tabular}{|c|c|}
\hline Simbol & Deskripsi \\
\hline Aktor & $\begin{array}{l}\text { Digunakan untuk } \\
\text { menggambarkan } \\
\text { user/pengguna }\end{array}$ \\
\hline Lifeline & $\begin{array}{l}\text { Menyatakan objek } \\
\text { entity, antramuka yang } \\
\text { saling berinteraksi }\end{array}$ \\
\hline Boundary & $\begin{array}{l}\text { Digunakan untuk } \\
\text { menggambarkan } \\
\text { sebuah form }\end{array}$ \\
\hline $\begin{array}{l}\text { Message } \\
\text { Message () }\end{array}$ & $\begin{array}{l}\text { Spesifikasi dari } \\
\text { komunikasi antar } \\
\text { objek yang memuat } \\
\text { informasi-informasi } \\
\text { tentang aktifitas yang } \\
\text { terjadi }\end{array}$ \\
\hline Control Class & $\begin{array}{l}\text { Digunakan untuk } \\
\text { menghubungkan } \\
\text { boundary dengan tabel }\end{array}$ \\
\hline Entity Class & $\begin{array}{l}\text { Digunakan untuk } \\
\text { menggambarkan } \\
\text { hubungan kegiatan } \\
\text { yang akan dilakukan }\end{array}$ \\
\hline
\end{tabular}

O. Class Diagram
Class diagram mendeskripsikan jenis-jenis objek dalam sistem dan berbagai macam hubungan statis yang terdapat di antara mereka. Class diagram juga menunjukkan properti dan operasi sebuah class dan batasanbatasan yang terdapat dalam hubunganhubungan objek tersebut. UML menggunakan istilah fitur sebagai istilah umum yang meliputi properti dan operasi sebuah class (Fowler, 2005, 53).

Berikut merupakan simbol-simbol yang digunakan dalam Class Diagram :

Tabel 4. Simbol Class Diagram

\begin{tabular}{|c|c|}
\hline Simbol & Deskripsi \\
\hline Generalization & $\begin{array}{l}\text { Hubungan dimana } \\
\text { objek anak } \\
\text { (descendent) } \\
\text { berbagi perilaku } \\
\text { dan struktur data } \\
\text { dari objek yang ada } \\
\text { di atasnya objek } \\
\text { induk (ancestor). }\end{array}$ \\
\hline Class & $\begin{array}{l}\text { Himpunan dari } \\
\text { objek-objek yang } \\
\text { berbagi attribut dan } \\
\text { operasi yang sama }\end{array}$ \\
\hline Collaboration & $\begin{array}{l}\text { Deskripsi dari } \\
\text { urutan aksi-aksi } \\
\text { yang ditampilkan } \\
\text { sistem yang } \\
\text { menghasilkan suatu } \\
\text { hasil yang terukur } \\
\text { bagi suatu aktor }\end{array}$ \\
\hline Realization & $\begin{array}{l}\text { Operasi yang } \\
\text { benar-benar } \\
\text { dilakukan oleh } \\
\text { suatu objek }\end{array}$ \\
\hline Dependency & $\begin{array}{l}\text { Hubungan dimana } \\
\text { perubahan yang } \\
\text { terjadi pada suatu } \\
\text { elemen mandiri } \\
\text { (independent) akan } \\
\text { mempengaruhi } \\
\text { elemen yang } \\
\text { bergantung } \\
\text { padanya elemen } \\
\text { yang tidak mandiri. }\end{array}$ \\
\hline
\end{tabular}

P. Metode Slovin

Pada penelitian ini, penulis menggunakan metode slovin untuk menentukan jumlah sampel. Rumus sederhana yang dikembangkan oleh slovin untuk penentuan sampel dapat dilihat pada buku "Metode Penelitian untuk skripsi dan Tesis Bisnis" 
yang ditulis oleh Husein Umar (2004). Berikut merupakan rumus dari metode slovin:

$$
N=\frac{n}{1+N e^{2}}
$$

Keterangan :

$\mathrm{N}=$ Jumlah Sampel

$\mathrm{n}=$ Jumlah Populasi

$\mathrm{e}=$ Persentase keloggaran ketidaktelitian

\section{Q. Black box testing}

Menurut Sinarmata (2010, 316), klasifikasi black box testing mencakup bebrapa pengujian salah satunya adalah pengujian fungsional (functional testing). Pada jenis pengujian ini, perangkat lunak diuji untuk persyaratan fungsional. Pengujian dilakukan dalam bentuk tertulis untuk memeriksa apakah aplikasi berjalan seperti yang diharapkan. Walaupun pengujian fungsional sudah sering dilakukan di bagian akhir dari siklus pengembangan, masing-masing komponen dan proses dapat diuji pada awal pengembangan. Pengujian fungsional meliputi seberapa baik sistem melaksanakan fungsinya, termasuk perintah-perintah pengguna, manipulasi data, pencarian dan proses bisnis, pengguna layar, dan integrasi.

\section{ANALISIS DAN PERANCANGAN \\ SISTEM \\ Metode Pengumpulan Data}

Metode pengumpulan data adalah metode yang digunakan untuk mengumpulkan data yang diperlukan selama penelitian dilakukan. Terdapat beberapa metode pengumpulan data yang digunakan dalam penelitian ini. Metode yang digunakan dalam penelitian ini adalah sebagai berikut:

\section{Wawancara}

Metode wawancara adalah metode yang dilakukan dengan melakukan wawancara langsung dengan pihak perusahaan. Dalam Metode ini dilakukan tanya jawab secara langsung kepada guru senior Bapak Hamid, M.Si. dari hasil wawancara tersebut, didapatkan informasi tentang masalah yang perlu diselesaikan dari sudut pandang pengajar. Kemudian dilanjutkan dengan tanya jawab singkat kepada beberapa siswa SMA Muhammadiyah 1 Denpasar. Dari hasil wawancara tersebut, didapatkan informasi dan solusi yang diharapkan dari kendala dalam kegiatan belajar dari sudut pandang siswa.

2. Metode Observasi

Metode ini dilakukan dengan cara melakukan pengamatan langsung ke objek penelitian untuk melihat dekat kegiatan belajar mengajar yang dilakukan. Metode observasi dilakukan untuk mendapatkan data mengenai sistem penyampaian materi, kuis, dan respon dari siswa tentang materi yang disampaikan.

3. Kuesioner

Dalam penelitian ini, penulis mengambil sampel sebanyak 61 orang dari total populasi sebanyak 529 orang. Jumlah sampel ini didapat dari penghitungan dengan metode slovin dengan total error $12 \%$. Pengambilan sampel sebanyak $12 \%$ yang ditentukan oleh penulis diperkuat dengan penentuan pengambilan sample yang dikemukakan oleh Arikunto $(2008,116)$ yaitu, apabila kurang dari 100 lebih baik diambil semua hingga penelitiannya merupakan penelitian populasi. Jika jumlah objeknya besar dapat diambil antara $10-15 \%$ atau $20-55 \%$.

4. Metode Kepustakaan

Data sekunder didapat dengan cara pengumpulan data dengan metode kepustakaan. Metode kepustakaan digunakan dengan cara mengumpukan data-data yang dibutuhkan melalui buku-buku referensi seperti perancangan UML, metode pengumpulan sampel dan buku-buku yang relevan dengan penelitian yang dilakukan.
A. Perancangan Sistem
Sebelum membangun suatu sistem maka terlebih dahulu dilakukan proses perancangan sistem, dimana berdasarkan analisis yang telah dilakukan maka dapat diketahui apa saja yang menjadi masukan sistem, keluaran sistem, metode yang digunakan oleh sistem, serta antarmuka sistem yang akan dirancang. 


\section{Use Case Diagram}

Dalam use case diagram terdapat 3 user yang akan menggunakan sistem. Dari operator, operator dapat melakukan manage kelas, manage data guru, logout, manage data diri, dan login. Guru dapat melakukan manage tugas, manage materi, mengupload E-book, manage quiz, manage data diri, download materi, login, dan logout. Siswa dapat melakukan manage data diri, download materi, download tugas, mengerjakan tugas, mengerjakan quiz, membaca E-book, login, dan logout. Gmbar 1 merupakan gambaran Use case diagram dari sistem yang dibangun.

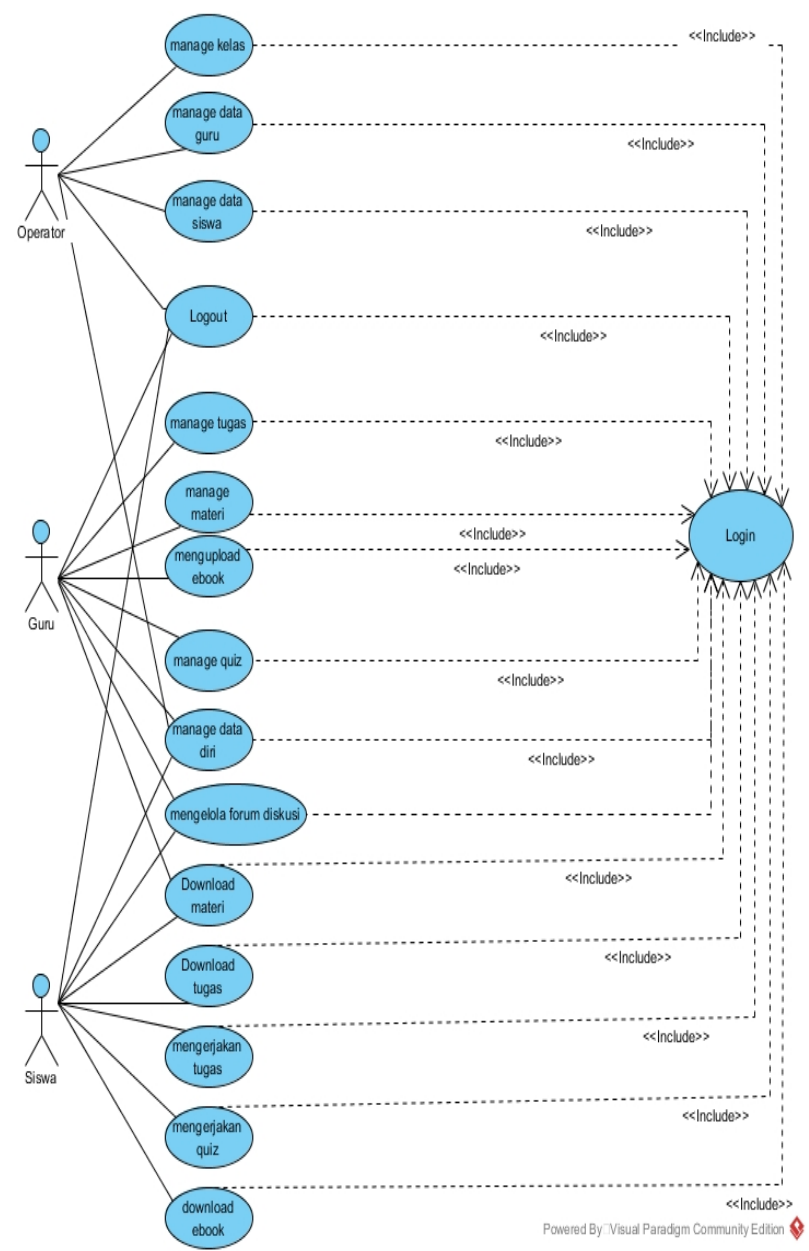

Gambar 1. Use Case Diagram

2. Activity Diagram

Beberapa activity diagram utama yang dijabarkan pada artikel ini diantaranya activity diagram manage materi dan download materi.

2.1 Activity Diagram manage materi (Guru)
Activity Diagram manage materi menggambarkan tentang manage data materi. Data materi meliputi upload dan download materi yang dilakukan oleh guru. Gambar 2

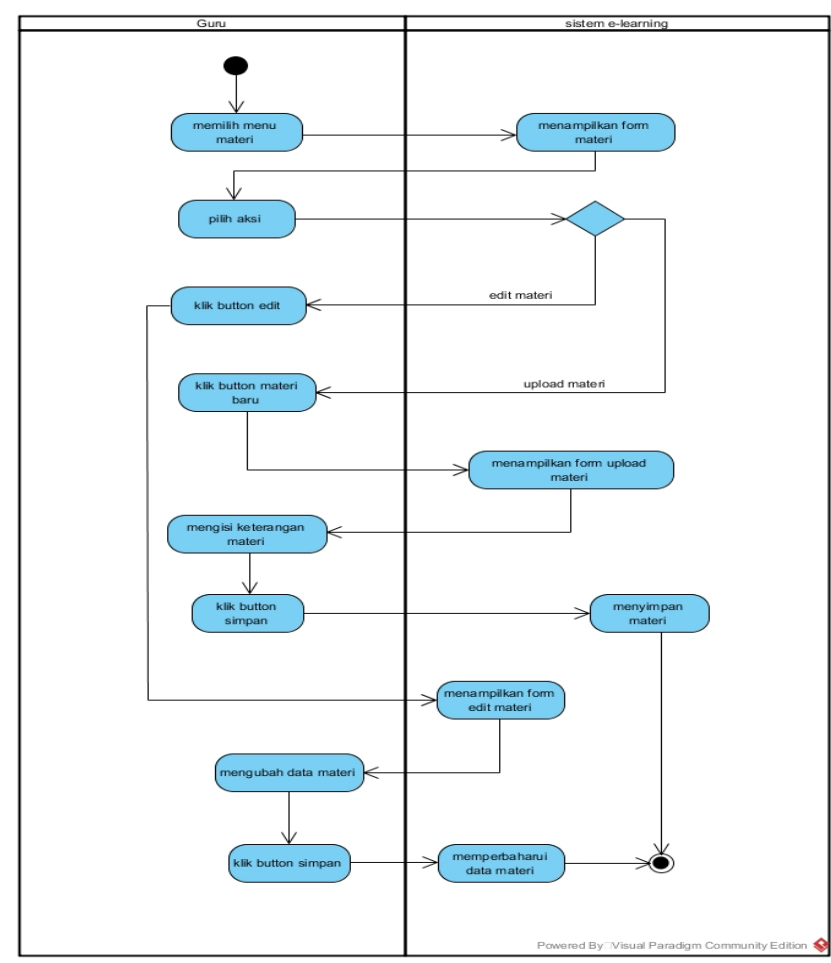

merupakan gambar dari Activity Diagram manage materi (Guru).

Gambar 2. Activity diagram manage materi

\subsection{Activity Diagram Download Materi}

(Siswa)

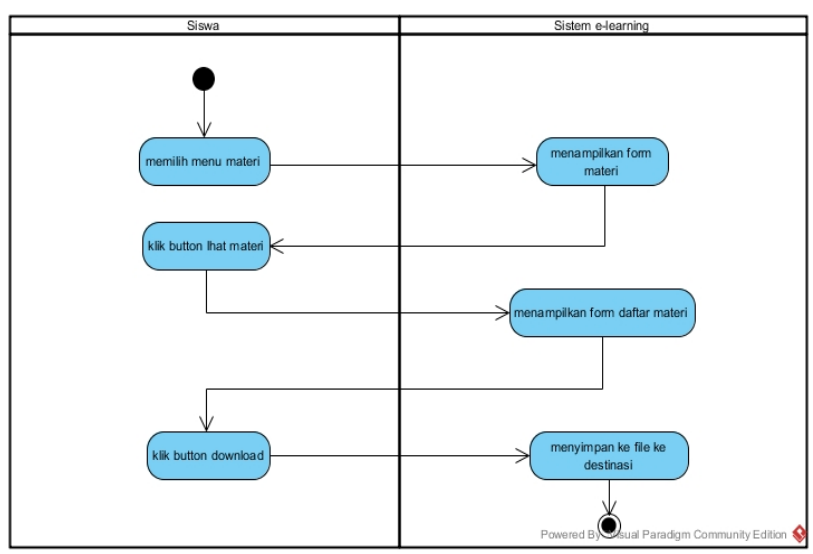

Gambar 3. Activity diagram Download Materi

Activity diagram Download materi menggambarkan tentang aktifitas download materi yang dilakukan oleh siswa. Gambar 3 merupakan gambar dari Activity Diagram download materi (Siswa). 


\section{Sequence Diagram}

Sequence diagram yang dibuat pada penelitian ini meliputi proses login, manage data guru, manage data siswa, manage kelas, manage materi, download materi, manage quiz, upload e-book, membaca e-book, dan mengerjakan tugas. Beberapa sequence diagram yang ditampilkan pada artikel ini meliputi sequence diagram pembuatan materi baru dan download materi.

\subsection{Sequence Diagram Materi Baru}

Sequence diagram manage materi (materi baru) menggambarkan proses membuat materi baru yang dilakukan guru. Gambar 4 merupakan gambar Sequence Diagram pembuatan materi baru.

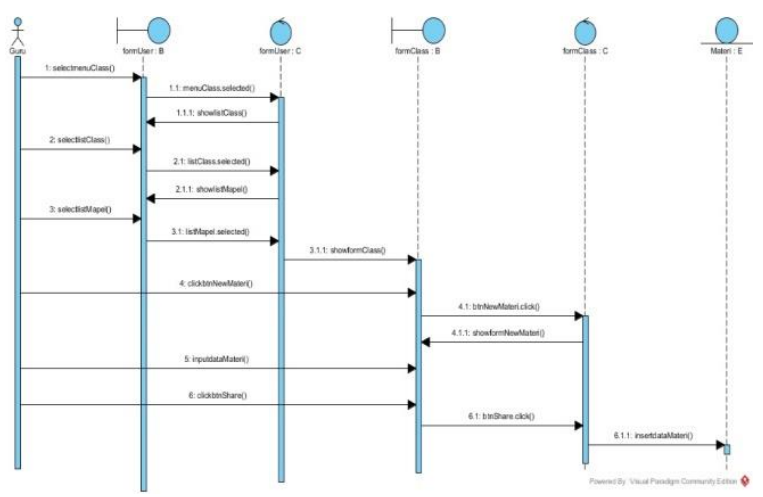

Gambar 4. Sequence Diagram Materi Baru

\subsection{Sequence Diagram Download Materi}

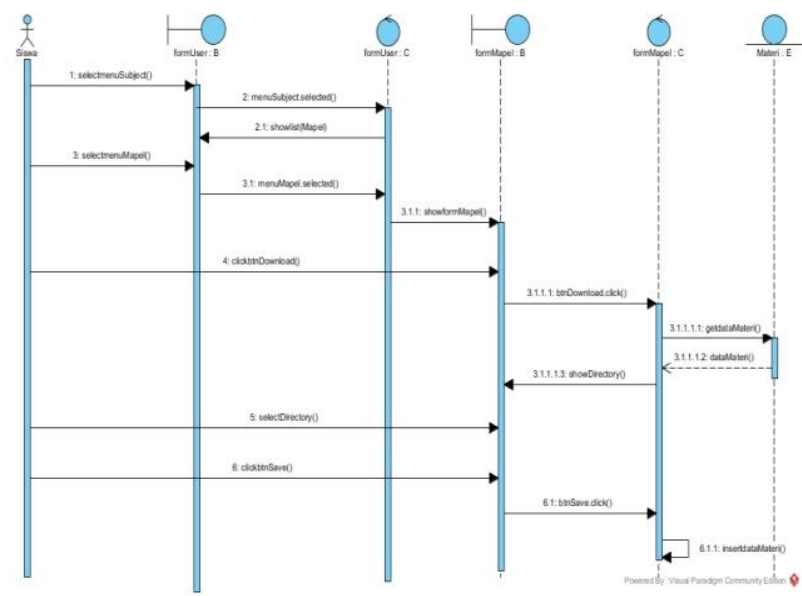

Gambar 5. Sequence Diagram Download Materi

Sequence diagram download materi (Siswa) menggambarkn proses download materi yang dilakukan oleh siswa. Gambar 5 merupakan gambar Sequence Diagram download materi. 4. Class Diagram
Dalam perancangan Class diagram, terdapat 7 entitas yaitu login, E-book, tugas, quiz, materi, class, dan user. Gambar 6 merupakan rancangan Class Diagram.

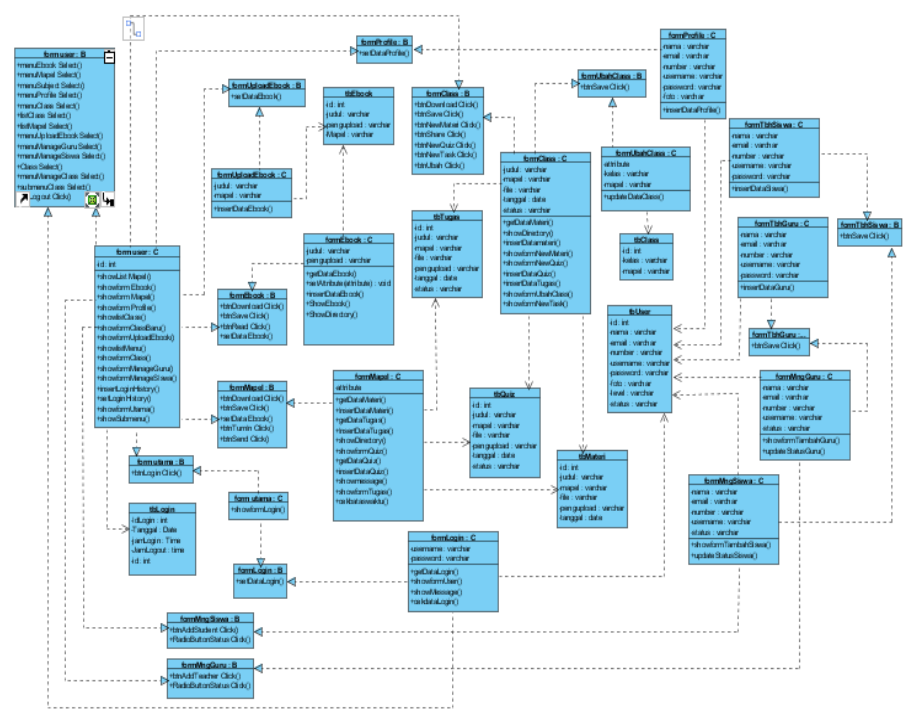

Gambar 6. Class Diagram

\section{HASIL DAN PEMBAHASAN}

Implementasi antarmuka ini bertujuan untuk menghubungkan pengguna dengan Media Pembelajaran Online (E-learning) Pada SMA Muhammadiyah 1 Denpasar. Adapun pengguna yang akan menggunakan sistem adalah siswa, guru, dan admin.

\section{Halaman Utama}

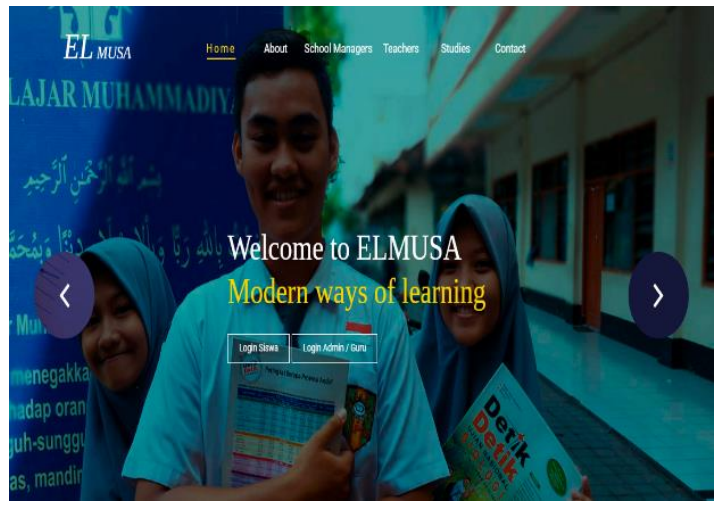

Gambar 7. Halaman Utama

Gambar 7 merupakan tampilan utama dari sistem, terdapat menu home, about, school managers, studies, dan contact. Untuk masuk ke form login, user harus memilih button 
Login Siswa atau Login Admin/Guru sesuai dengan user yang akan menggunakan sistem.

\section{Tampilan Halaman User}

Gambar 8 merupakan tampilan halaman user untuk admin setelah menginputkan username dan password yang sesuai dengan hak aksesnya.
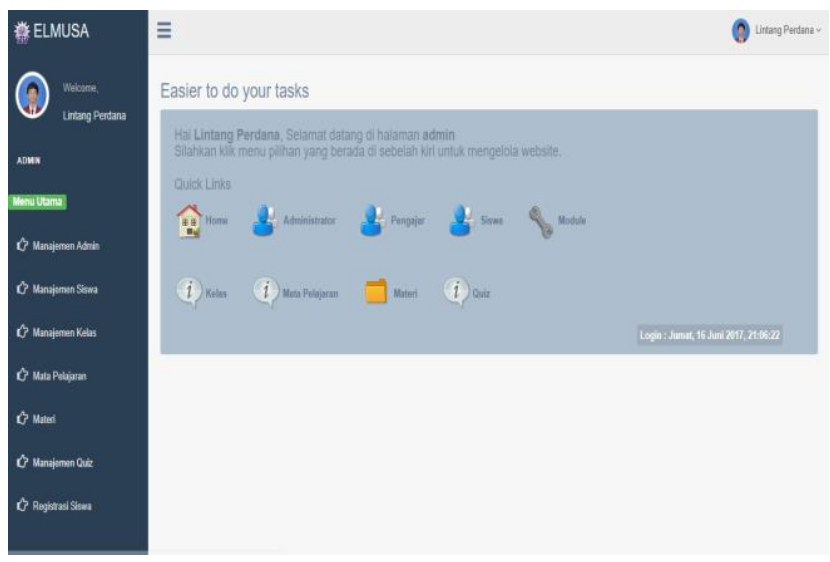

Gambar 8. Halaman User (Admin)

\section{Tampilan Tabel Materi}

Gambar 9 merupakan tampilan Tabel Materi.

Tabel materi menampilkan data materi, dan dapat menambahkan materi beserta mengubah data materi.
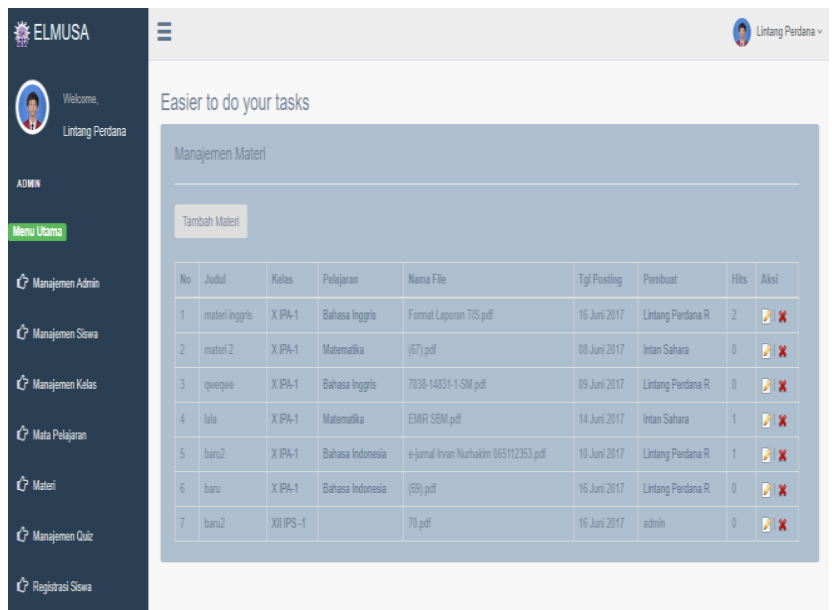

Gambar 9. Halaman Data Materi

4. Tampilan Halaman Tambah Quiz/Tugas Pilihan Ganda

Gambar 10 merupakan tampilan jika guru berhasil menambahkan data tugas atau quiz pilihan ganda. Guru dapat menambah data tugas atau quiz kemudian klik button simpan.

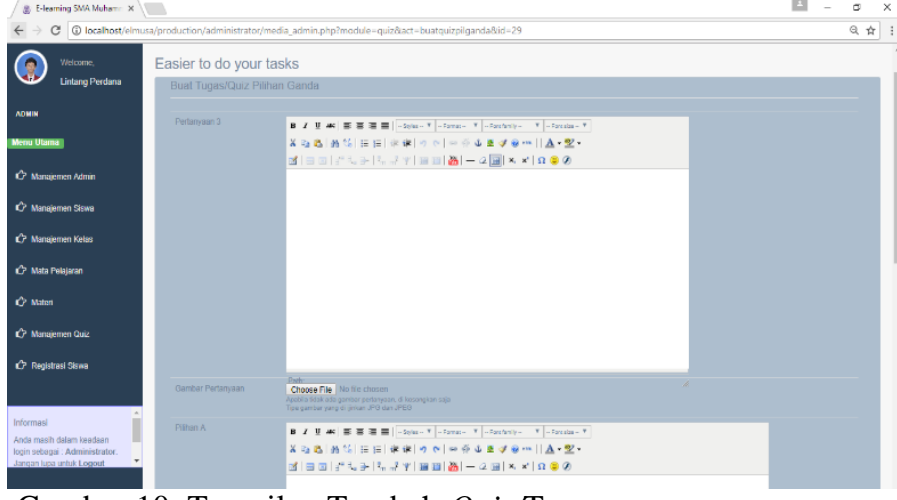

Gambar 10. Tampilan Tambah Quiz/Tugas

5. Tampilan Halaman Download Materi Pada halaman Download Materi, siswa dapat mendownload Materi dengan klik button download file kemudian akan muncul direktori untuk menyimpan materi. Gambar 11 merupakan tampilan halaman Download Materi.

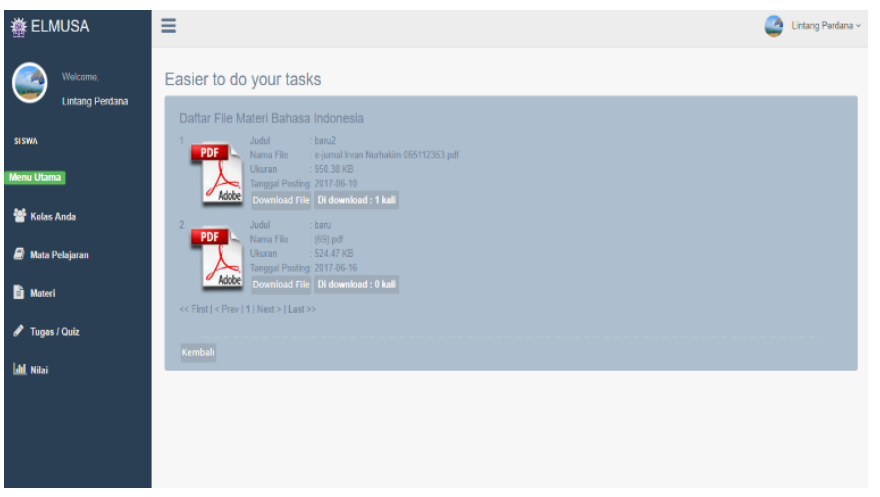

Gambar 11. Halaman Download Materi

\section{SIMPULAN}

Permasalahan yang terdapat pada SMA Muhammadiyah 1 Denpasar yaitu kegiatan belajar mengajar yang terganggu karena guru memiliki kesibukan diluar sekolah, sehingga kelas menjadi sering kosong dan guru mengalami kesulitan dalam mengelola tugas dan menyampaikan materi kepada siswa. Proses perancangan Media Pembelajaran Online (E-learning) pada SMA Muhammadiyah 1 Denpasar dimulai dari pengumpulan data yang dibutuhkan dalam pembuatan e-learning, selanjutnya melakukan perancangan sistem dengan menggunakan UML (Unified Modelling Language) yang terdiri dari Use Case Diagram, Activity Diagram, Sequence 
Diagram, dan Class Diagram. Dilanjutkan dengan merancang user interface yang akan dibangun. Langkah terakhir melakukan uji coba sistem. Fitur-fitur yang terdapat pada $e$ learning adalah mengelola data siswa, mengelola data guru, mengelola data materi, mengelola data tugas dan quiz, mengelola data $e$-book, dan adanya forum diskusi yang dapat digunakan untuk berdiskusi antara guru dan siswa.

\section{DAFTAR PUSTAKA}

[1] Arikunto, Suharsimi. 2006. Metodelogi penelitian. Yogyakarta: Andi Publisher

[2] Boettcher,Judith. V.1999 .Faculty Guide For Moving Teaching and Learning to The Web, League For Inovation In The Community College.USA.

[3] Firdaus. 2007. 7 Jam Belajar Interaktif PHP \& MySql dengan Dreamweaver. Palembang: Maxikom

[4] Fowler, Martin. 2005. UML Distilled Edisi 3. Yogyakarta: Penerbit Andi.

[5] Hakim, Lukman. 2009. Trik Rahasia Master PHP Terbongkar Lagi. Yogyakarta: Andi Offset.

[6] Hanif, Al Fatta. 2007. Analisis \& Perancangan Sistem Informasi untuk Keunggulan Bersaing Perusahaan dan Organisasi Modern. Yogyakarta: Penerbit Andi.

[7] Hidayatullah. Priyanto, Kawistara. Jauhari K. 2014. Pemrograman Web. Bandung: Informatika.

[8] Hutahaean, Jeperson. 2014. Konsep Sistem Informasi. Yogyakarta: Deepublish.

[9] Ibrahim. 2008. Cara Praktis Membuat Website Dinamis Menggunakan Xampp. Yogyakarta: Neotekno.

[10] Jaya Kumar C. Koran, 2002. Aplikasi Elearning dalam pengajaran dan pembelajaran di Sekolah Malaysia. Malaysia.

[11] Jogiyanto, 2005. Analisis dan Desain Sistem Informasi. Yogyakarta: Penerbit Andi.

[12] Jogiyanto. 2009. Analisis dan Desain. Yogyakarta: Andi.

[13] Mulyanto, Agus. 2009. Sistem Informasi Konsep dan Aplikasi. Yogyakarta: Pustaka Pelajar.

[14] Permana, P. 2010. Efektifitas Penggunaan Aplikasi Learning Management Sistem (LMS) untuk Meningkatkan

Kemampuan
Membaca Mahasiswa Bahasa Jerman di Universitas Pendidikan Indonesia. Tesis. Program Studi Pengembangan Kurikulum, Pasca Sarjana, UPI.

[15] Pohan, Iskandar. 2014. Pemrograman Web dengan HTML. Informatika Bandung : Bandung

[16] Prasetyo, Didik Dwi. 2004. Aplikasi Database Client/Server Menggunakan Delphi dan MySql. Jakarta: PT.Elex Media Komputindo

[17] Pratama. 2016. Rancang Bangun Elearning untuk mata pelajaran akuntansi kelas 11 IPA dan IPS (Studi kasus SMA Negeri 8 Denpasar). S. Kom. STMIK STIKOM INDONESIA.

[18] Rosa, A.S dan Salahuddin M. 2013. Modul Pembelajaran Rekayasa Perangkat Lunak (Terstruktur dan Berorientasi Objek). Bandung: Modula.

[19] Sinarmata. 2010. Basis Data. Yogyakarta: Andi Publisher.

[20] Rosenberg, M. J. 2001. E-learning: Strategies for delivering knowledge in the digital age. New York: McGrawHill.

[21] Sugiyono. 2010. Metode Penelitian Pendidikan. Bandung: Alfabeta.

[22] Sutabri, T. 2012. Analisis Sistem Informasi. Yogyakarta: Andi.

[23] Sriwihajriyah. 2012. "Sistem Pembelajaran dengan E-learning untuk persiapan ujian naional pada SMA PUSRI Palembang". Jurnal Sistem Informasi 4: 450-467.

[24] Umar, Husein. 2004. Metode penelitian untuk skripsi dan tesis bisnis. Jakarta: PT. Grafindo Persada.

[25] Yazdi, M. 2012.E-learning Sebagai Media Pembelajaran Interaktif Berbasis Teknologi Informasi. Tadukalox. 